Supporting Information:

\title{
A $\mathrm{Zn}\left(\mathrm{ClO}_{4}\right)_{2}$ Electrolyte Enabling Long-Life Zinc Metal Electrodes for Rechargeable Aqueous Zinc Batteries
}

Lijun Wang, ${ }^{+}$Yue Zhang, ${ }^{+}$Honglu Hu, Hua-Yu Shi, Yu Song, Di Guo, Xiao-Xia Liu, Xiaoqi Sun*

Department of Chemistry, Northeastern University, Shenyang, 110819, China.

$\$$ - These authors contributed equally to this work.

Corresponding Author

*E-mail: sunxiaoqi@mail.neu.edu.cn 


\section{Experimental Method}

Material synthesis and characterization. The electrolytes were obtained by dissolving desired amount of $\mathrm{Zn}\left(\mathrm{ClO}_{4}\right)_{2} \cdot 6 \mathrm{H}_{2} \mathrm{O}, \mathrm{ZnSO}_{4} \cdot 7 \mathrm{H}_{2} \mathrm{O}, \mathrm{Zn}\left(\mathrm{CH}_{3} \mathrm{COO}\right)_{2} \cdot 2 \mathrm{H}_{2} \mathrm{O}$, or $\mathrm{Zn}\left(\mathrm{CF}_{3} \mathrm{SO}_{3}\right)_{2}$ in deionized water. Trace precipitate showed up in $\mathrm{Zn}\left(\mathrm{ClO}_{4}\right)_{2}$ electrolyte which could be a result of slight hydrolysis of the salt, so that the mixture was settled and the clear liquid was used as the electrolyte. Zn concentration in the $\mathrm{Zn}\left(\mathrm{ClO}_{4}\right)_{2}$ electrolyte was measured with Agilent ICPOES730. $\mathrm{VO}_{2}$ was synthesized by a similar procedure reported previously, ${ }^{1}$ except for the utilization of microwave-assisted hydrothermal reaction rather than a conventional one. Typically, $\mathrm{V}_{2} \mathrm{O}_{5}$ and oxalate acid were dissolved in deionized water in a glass vessel and fitted in Monowave 200 synthesis system (Anton Paar). The temperature of the system was increased to $75^{\circ} \mathrm{C}$ and stayed for $5 \mathrm{~min}$, followed by the further increase of temperature to $180{ }^{\circ} \mathrm{C}$ and stayed for $10 \mathrm{~min}$. After cooling to room temperature, the mixture was filtered and washed with deionized water and ethanol. X-ray diffraction (XRD) analysis was carried out on a PANalytical Empyrean diffractometer with $\mathrm{Cu}-\mathrm{K} \alpha$ or $\mathrm{Co}-\mathrm{K} \alpha$ radiation. Material morphologies were examined by a HITACHI SU8010 scanning electron microscope (SEM) equipped with an energy dispersive X-ray spectroscopy (EDS) detector.

Electrochemistry. Zinc electrodes were cut into $13.5 \mathrm{~mm}$ diameter circles from zinc foil. $\mathrm{VO}_{2}$ electrodes were prepared by mixing $\mathrm{VO}_{2}$ with Super $\mathrm{P}$ and polyvinylidene fluoride (PVDF) in an 8:1:1 weight ratio in N-methyl-2-pyrrolidone (NMP). The slurry was casted onto carbon paper and dried. Zn stripping/plating (with Zn-Zn symmetric configuration), coulombic efficiency (copper foil as the cathode current collector), $\mathrm{VO}_{2}$ cyclic voltammogram $(\mathrm{CV})$, rate performance and cycling tests were carried out in 2032 coin cells with LANHE CT2001A battery cycler or Bio-logic VMP3 potentiostat/galvanostat. Electrochemical impedance spectroscopy (EIS) was obtained in T-shaped PFA Swagelok cells with Zn (11.5 mm diameter) as the working, counter and reference electrodes on the Bio-logic VMP3 potentiostat/galvanostat. The CV of the electrolyte was obtained in a beaker cell with Ti foil as the cathode and $\mathrm{Zn}$ foil as the anode on the Bio-logic VMP3 potentiostat/galvanostat. 


\section{Supporting Figures}
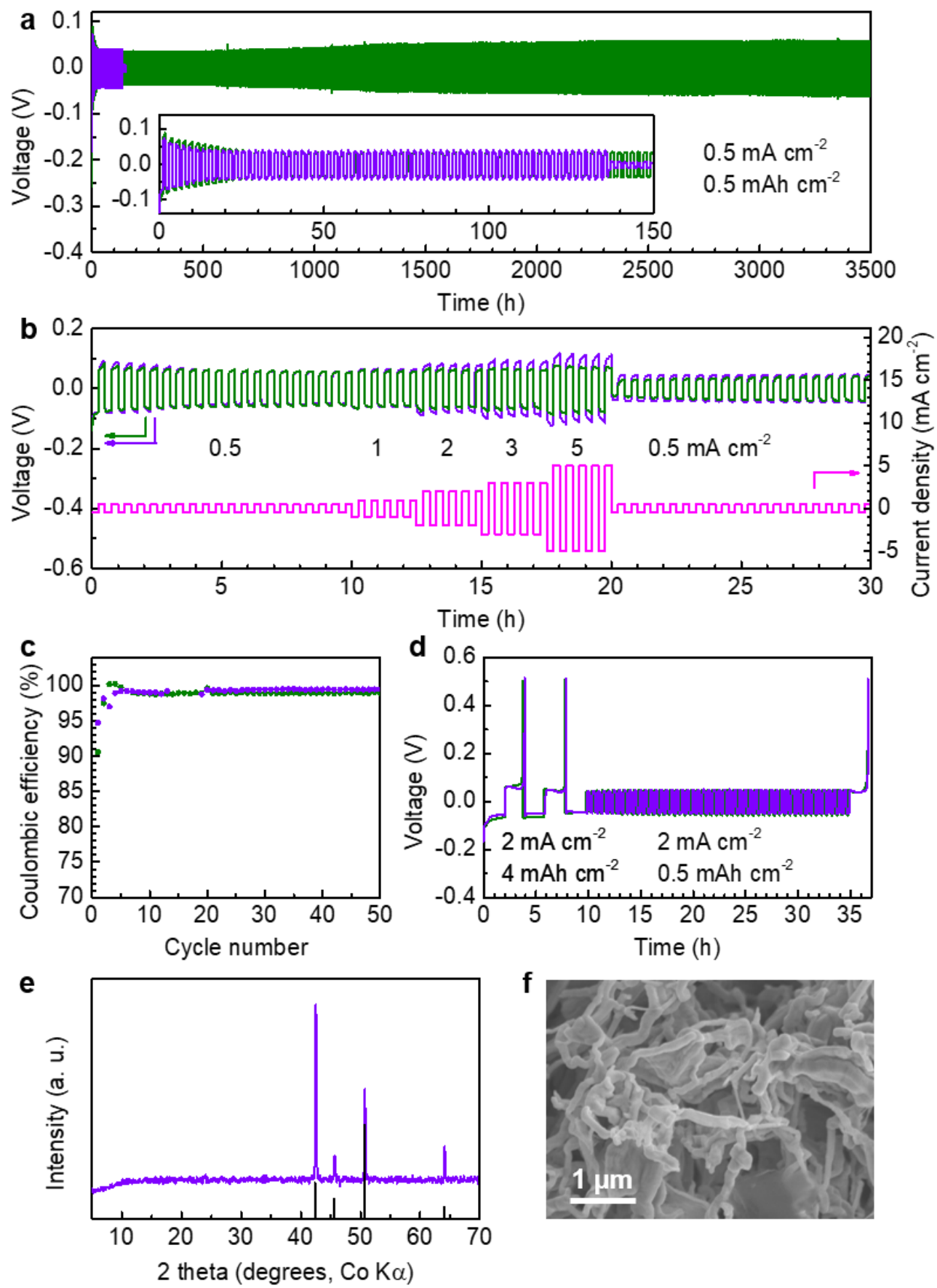

Figure S1. Zn stripping/plating behavior in symmetric cells at (a) $0.5 \mathrm{~mA} \mathrm{~cm}^{-2}$ current density and 0.5 $\mathrm{mAh} \mathrm{cm}^{-2}$ capacity (inset shows the first 150 hour behavior) and (b) various current densities in $\mathrm{Zn}\left(\mathrm{CF}_{3} \mathrm{SO}_{3}\right)_{2}$ (purple) and $\mathrm{Zn}\left(\mathrm{ClO}_{4}\right)_{2}$ (green) electrolytes; $\mathrm{CE}$ tests with $\mathrm{Cu}$ current collectors in $\mathrm{Zn}\left(\mathrm{CF}_{3} \mathrm{SO}_{3}\right)_{2}$ (purple) and $\mathrm{Zn}\left(\mathrm{ClO}_{4}\right)_{2}$ (green) electrolytes: (c) full $\mathrm{Zn}$ stripping/plating $\mathrm{CE}$ and (d) partial Zn stripping/plating voltage profiles; (e) XRD (black peaks show the Zn diffractions) and (f) SEM image of the $\mathrm{Zn}$ electrode after deposition of $2 \mathrm{mAh} \mathrm{cm}^{-2} \mathrm{Zn}$ at $0.5 \mathrm{~mA} \mathrm{~cm}^{-2}$ from the $\mathrm{Zn}\left(\mathrm{CF}_{3} \mathrm{SO}_{3}\right)_{2}$ electrolyte. 


\section{Discussion on the electrochemical performance comparison of $\mathrm{Zn}\left(\mathrm{CF}_{3} \mathrm{SO}_{3}\right)_{2}$ and $\mathrm{Zn}\left(\mathrm{ClO}_{4}\right)_{2}$ electrolytes:}

Figure S1a-d above shows the electrochemical performance comparison between $\mathrm{Zn}\left(\mathrm{CF}_{3} \mathrm{SO}_{3}\right)_{2}$ and $\mathrm{Zn}\left(\mathrm{ClO}_{4}\right)_{2}$ electrolytes. The symmetric cell with $\mathrm{Zn}\left(\mathrm{CF}_{3} \mathrm{SO}_{3}\right)_{2}$ electrolyte short-circuits before 140 hours of Zn stripping/plating (Figure S1a). Similar early cell degradation has also been shown in previous publications. ${ }^{2-6}$ The cycle life is significant shorter than the over 3500 hours for $\mathrm{Zn}\left(\mathrm{ClO}_{4}\right)_{2}$. With the increase of current density, the overpotential increase in $\mathrm{Zn}\left(\mathrm{ClO}_{4}\right)_{2}$ is smaller than $\mathrm{Zn}\left(\mathrm{CF}_{3} \mathrm{SO}_{3}\right)_{2}$ (Figure S1b), suggesting the better rate capability of the former. When measuring coulombic efficiency (CE), the cell with $\mathrm{Zn}\left(\mathrm{CF}_{3} \mathrm{SO}_{3}\right)_{2}$ electrolyte shows partial cell degradation during the 15 th $\sim 20$ th cycle. An average $\mathrm{CE}$ of $99.4 \%$ was obtained using the data after 20 th cycle, similar to the $99.0 \% \mathrm{CE}$ for the $\mathrm{Zn}\left(\mathrm{ClO}_{4}\right)_{2}$ electrolyte (Figure S1c). Using the protocol proposed by Zhang et al. ${ }^{7}$ to evaluate CE also gives similar results for the two electrolytes, i.e. $99.3 \%$ for $\mathrm{Zn}\left(\mathrm{ClO}_{4}\right)_{2}$ and $98.6 \%$ for $\mathrm{Zn}\left(\mathrm{CF}_{3} \mathrm{SO}_{3}\right)_{2}$ (Figure S1d).

Figure S1e shows the XRD of the $\mathrm{Zn}$ electrode after depositing $2 \mathrm{mAh} \mathrm{cm}^{-2} \mathrm{Zn}$ from $\mathrm{Zn}\left(\mathrm{CF}_{3} \mathrm{SO}_{3}\right)_{2}$ electrolyte, where only $\mathrm{Zn}$ diffractions are identified. The corresponding SEM image suggests the dendritic morphology of the deposited Zn (Figure S1f). 

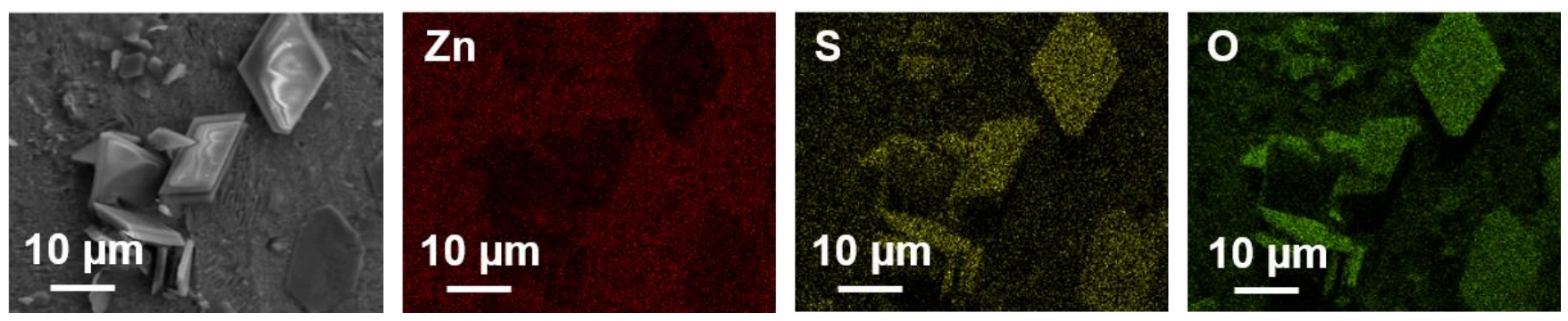

Figure S2. EDS mapping of the $\mathrm{Zn}$ electrode after 50 stripping/plating cycles in $\mathrm{ZnSO}_{4}$.

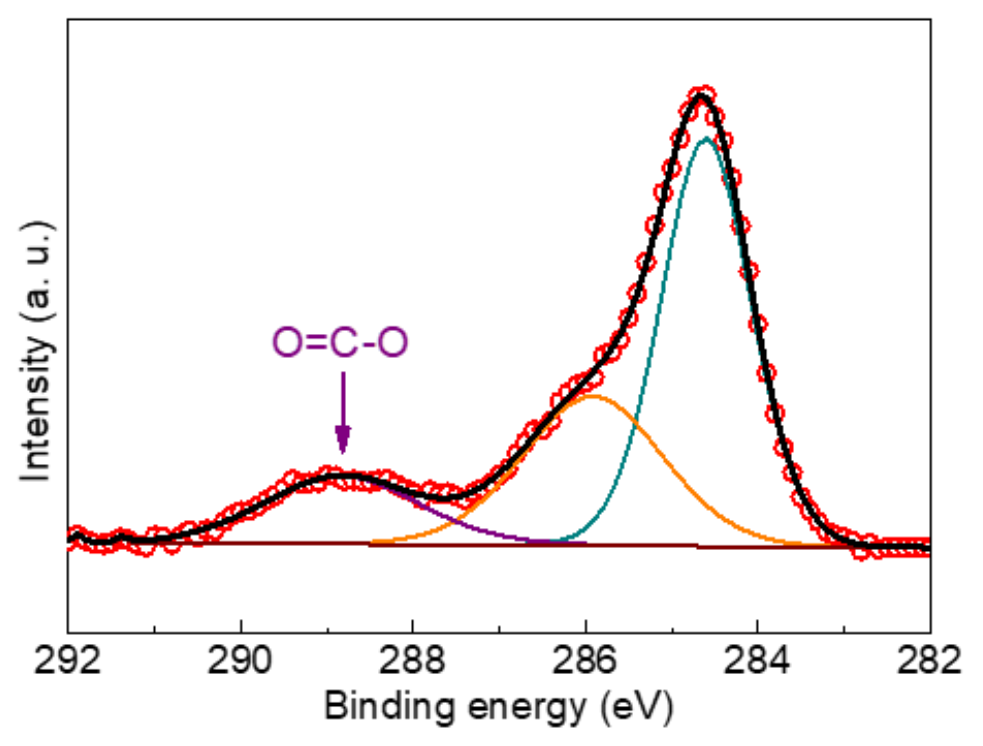

Figure S3. The fitting of $\mathrm{C} 1 \mathrm{~s}$ XPS of the $\mathrm{Zn}$ electrode after one deposition in $\mathrm{Zn}\left(\mathrm{CH}_{3} \mathrm{COO}\right)_{2}$. 


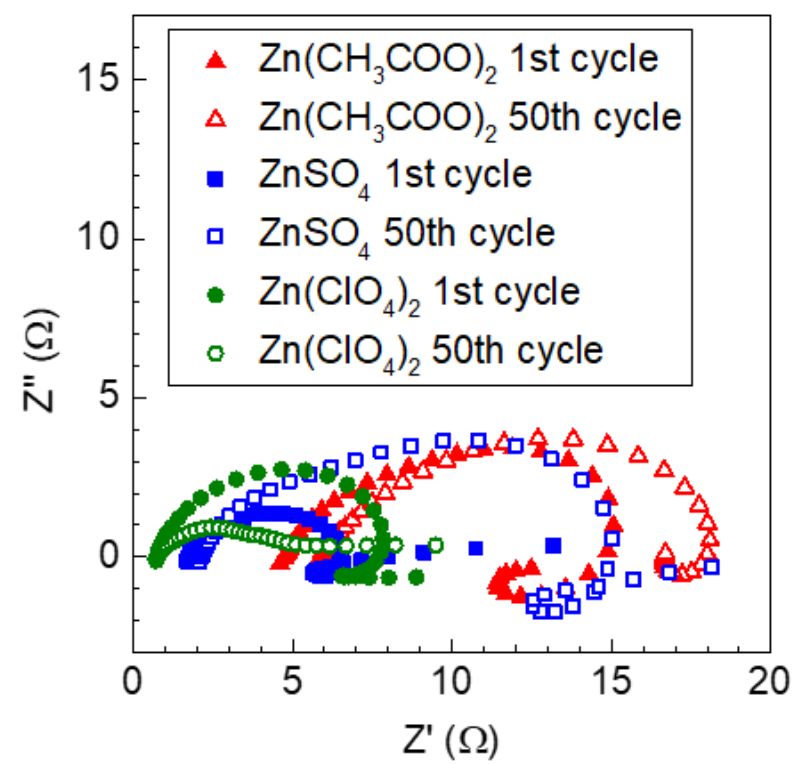

Figure S4. EIS of the $\mathrm{Zn}$ electrodes in $\mathrm{ZnSO}_{4}$ (blue), $\mathrm{Zn}\left(\mathrm{CH}_{3} \mathrm{COO}\right)_{2}$ (red) and $\mathrm{Zn}\left(\mathrm{ClO}_{4}\right)_{2}$ (green) electrolytes at the first and $50^{\text {th }}$ cycles.

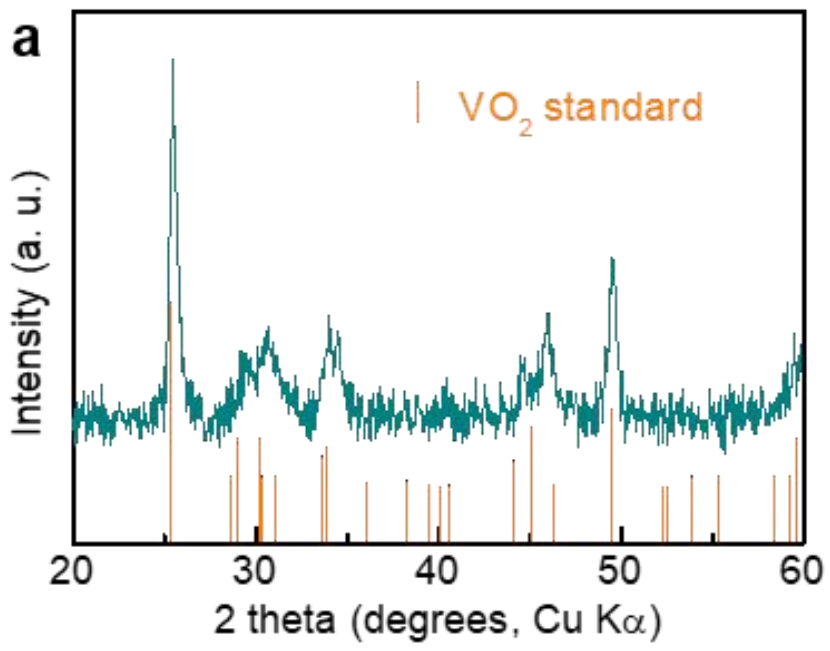

b

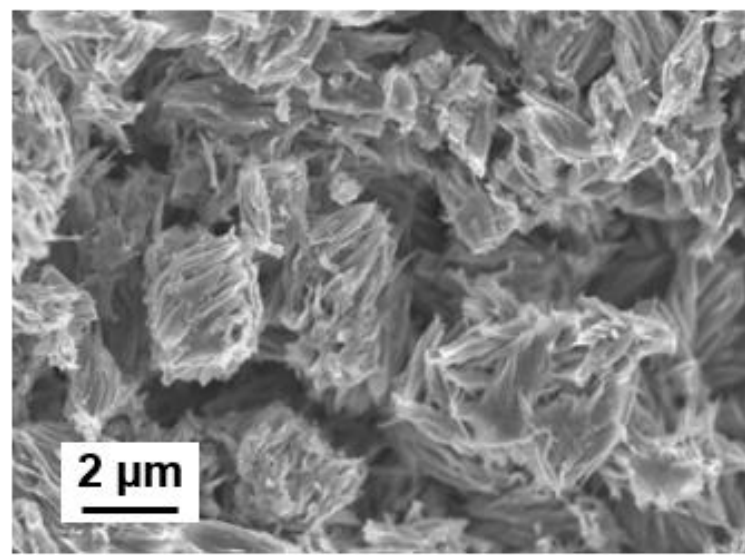

Figure S5. (a) XRD and (b) SEM image of $\mathrm{VO}_{2}$. 


\section{References}

(1) Ding, J.; Du, Z.; Gu, L.; Li, B.; Wang, L.; Wang, S.; Gong, Y.; Yang, S. Ultrafast Zn ${ }^{2+}$ Intercalation and Deintercalation in Vanadium Dioxide. Adv. Mater. 2018, 30, 1800762.

(2) Li, W.; Wang, K.; Cheng, S.; Jiang, K. A Long-Life Aqueous Zinc-Ion Battery Based on $\mathrm{Na}_{3} \mathrm{~V}_{2}\left(\mathrm{PO}_{4}\right)_{2} \mathrm{~F}_{3}$ Cathode. Energy Storage Mater. 2018, 15, 14-21.

(3) Naveed, A.; Yang, H.; Yang, J.; Nuli, Y.; Wang, J. Highly Reversible and Safe Zn Rechargeable Batteries Based on Triethyl Phosphate Electrolyte. Angew. Chem. Int. Ed. 2019, 58, 2760-2764.

(4) Naveed, A.; Yang, H.; Shao, Y.; Yang, J.; Nuli, Y.; Liu, J.; Shi, S.; Zhang, L.; Ye, A.; He, B.; Wang, J. A Highly Reversible Zn Anode with Intrinsically Safe Organic Electrolyte for Long-Cycle-Life Batteries. Adv. Mater. 2019, 1900668.

(5) Li, W.; Wang, K.; Cheng, S.; Jiang, K. An Ultrastable Presodiated Titanium Disulfide Anode for Aqueous “Rocking-Chair” Zinc Ion Battery. Adv. Energy Mater. 2019, 9, 1900993.

(6) Xu, W.; Zhao, K.; Huo, W.; Wang, Y.; Yao, G.; Gu, X.; Cheng, H.; Mai, L.; Hu, C.; Wang, X. Diethyl Ether as Self-Healing Electrolyte Additive Enabled Long-Life Rechargeable Aqueous Zinc Ion Batteries. Nano Energy 2019, 62, 275-281.

(7) Adams, B. D.; Zheng, J.; Ren, X.; Xu, W.; Zhang, J.-G. Accurate Determination of Coulombic Efficiency for Lithium Metal Anodes and Lithium Metal Batteries. Adv. Energy Mater. 2018, 8, 1702097. 